Research

\title{
Correlation between score for allergic rhinitis and quality of life in chronic rhinitis patients
}

\author{
Asti Widuri*, Triwahyuliati**, Winda Retno Ningrum*** \\ *Department of Health, Ear, Nose and Throat, Faculty of Medicine and Health Sciences \\ Universitas Muhammadiyah Yogyakarta \\ **Department of Neuroscience, Faculty of Medicine and Health Sciences, Universitas \\ Muhammadiyah Yogyakarta \\ ***Faculty of Medicine and Health Sciences Universitas Muhammadiyah Yogyakarta
}

\begin{abstract}
Background: Allergic rhinitis is a chronic inflammatory condition of the nasal mucosa that occurs as an Imunoglobulin E (IgE) mediated reaction after provocation of allergen. The prevalence of rhinitis in Indonesia reaches $12.4 \%$ and still rising. Chronic rhinitis can affect the quality of life, especially daily activities and sleep disturbances. Purpose: This study aimed to determine the correlation between the Score for Allergic Rhinitis (SFAR) and the patient's quality of life (QOL) using allergic rhinitis mobile phone application. Method: This was an observational analytic research using cross sectional method. The number of samples was 46 with predetermined inclusion and exclusion criteria. The research instrument used was a mobile phone application of SFAR and for quality of life was Visual Analog Scales (VAS) questionnaire. Data analysis was using Shapiro-Wilk for normality test and contingency coefficient test to determine the correlation between variables. Result: The result showed that there was a significant correlation between the Score for Allergic Rhinitis and the quality of life in chronic rhinitis sufferers $(\mathrm{p}=0.000)$. The correlation had uni-direction and moderate strength $(\mathrm{r}=0.567)$. There were $52.17 \%$ respondents who stated that rhinitis complaints would be reduced after using nasal drugs/sprays. And for the VAS parameter, the highest number given was 0 in $45.65 \%$ respondents, which meant that they did not feel any discomfort. Conclusion: There was a significant correlation between SFAR and quality of life AR sufferers with moderate strength and uni-direction.
\end{abstract}

Keywords: Score for Allergic Rhinitis, quality of life, rhinitis, mobile application

\section{ABSTRAK}

Latar belakang: Rinitis alergi adalah kondisi inflamasi kronis pada mukosa hidung sebagai reaksi yang dimediasi Imunoglobulin E (IgE) setelah provokasi alergen. Prevalensi rinitis di Indonesia mencapai 12,4\% dan akan terus meningkat. Rinitis kronik dapat memengaruhi kualitas hidup terutama aktivitas sehari-hari dan gangguan tidur. Tujuan: Penelitian ini bertujuan untuk mengetahui korelasi Score for Allergic Rhinitis (SFAR) dengan kualitas hidup penderita menggunakan aplikasi rinitis alergi pada telepon genggam. Metode: Penelitian ini berupa analitik observasional dengan desain cross sectional. Sampel yang digunakan sebanyak 46 responden dengan kriteria inklusi dan eksklusi yang sudah ditentukan. Instrumen penelitian menggunakan aplikasi telepon genggam berisi kuisioner SFAR dan kualitas hidup dengan Visual Analog Scales (VAS). Analisis data menggunakan ShapiroWilk untuk uji normalitas dan uji koefisien kontingensi untuk mengetahui korelasi antar variabel. Hasil: Didapatkan hasil berupa hubungan korelasi yang bermakna antara skor SFAR dengan kualitas hidup penderita rinitis kronik ( $p=0,000)$. Hubungan korelasi tersebut memiliki satu arah dan kekuatan yang sedang $(r=0,567)$. Diperoleh pernyataan dari $52,17 \%$ responden bahwa keluhan rinitis akan berkurang setelah minum obat/menggunakan semprot hidung. Untuk parameter VAS didapatkan hasil bahwa angka terbanyak yang diberikan adalah 0 pada 45,65\% responden, yang berarti tidak merasakan ketidaknyamanan. Kesimpulan: Terdapat korelasi bermakna antara SFAR dan kualitas hidup penderita AR dengan kekuatan hubungan sedang dan satu arah. 
Kata kunci: Score for Allergic Rhinitis, kualitas hidup, rinitis, aplikasi telepon genggam

Correspondence address: Asti Widuri, Department of Health, Ear, Nose and Throat, Faculty of Medicine and Health Sciences, Universitas Muhammadiyah Yogyakarta. Email: astiwiduri@gmail.com

\section{INTRODUCTION}

Allergic rhinitis is a chronic inflammatory condition of the nasal mucosa that occurs as an $\mathrm{IgE}$ mediated reaction after provocation of allergen. The main clinical symptoms of allergic rhinitis are nasal congestion/ obstruction, rhinorrhea (mucous nasal discharge), nasal itching and sneezing. Inflammation process could also affect the lower airways, therefore allergic rhinitis and asthma commonly coexists. ${ }^{1}$

Score for Allergic Rhinitis (SFAR) is a standard screening instrument in diagnosing allergic rhinitis as well as to find out the prevalence rate, contains various questions with a range score from 0 to 16 . SFAR is useful for determining the diagnosis of allergic rhinitis easily and quickly if the score is $\geq 7$, and not allergic rhinitis if the score is $<7 .^{2}$

The information components of SFAR questionnaire were (1) nasal symptoms in the last 12 months, such as sneezing, runny nose and nasal congestion; (2) nasal symptoms accompanied by itchy/watery eyes (rhinoconjunctivitis); (3) in what month or season nasal symptoms occur; (4) precipitating factors for nasal symptoms such as house dust, pollen, et cetera; (5) awareness of allergy status; (6) positive skin prick test (7) previous medical diagnosis of allergic diseases (asthma, skin allergy, allergic rhinitis); and (8) family history of allergy; where the score of each question is between 1-2. SFAR have been adapted, culturally translated into Bahasa Indonesia and validated as a screening tool of AR. ${ }^{3,4}$
Chronic rhinitis, although not fatal, can affect patient's daily activities, including life, work and studies, so that it could disturb the quality of life (QOL), social comfort and psychological well-being. It also aggravate comorbid condition and require medical cost. ${ }^{5}$ Rhinitis is often underestimated by sufferers so that complications are often found related to other diseases such as asthma, sinusitis, polyps, and otitis media. ${ }^{6}$

SFAR can be used as a quantitative and subjective measurement of a person's condition in addition to diagnosing allergic rhinitis, it also can estimate the severity and whether it is prolonged to cause a decrease in QOL. The level of quality of life could be measured with various instruments, one of which is using a Visual Analogue Scales questionnaire (VAS). ${ }^{7}$ By using a mobile phone application, the initial screening process and QOL assessment can be carried out independently by people who have symptoms of allergic rhinitis, thus providing guidance on whether to follow-up consultations with doctors to get therapy or with independent therapy based on its impact on QOL. ${ }^{8,9}$

One of the targets in allergic rhinitis therapy is to maintain a good QOL, so symptom information and continuity in the SFAR questionnaire is needed to determine the therapy and prognosis that are useful for achieving the most optimal QOL for rhinitis sufferers. This study aimed to determine the correlation between the SFAR and the QOL for chronic rhinitis sufferers whose assessment used a mobile phone application. 


\section{METHOD}

This was an observational analytic study using a cross sectional design and was approved by the ethics committee. The respondents were 46 students of $7^{\text {th }}$ semester Faculty of Medicine and Health Sciences, Universitas Muhammadiyah Yogyakarta, who had nasal complaints. The instrument used was in the form of user data for the application "Recognize and Control Allergic Nose" to determine the Score for Allergic Rhinitis and the quality-of-life questionnaire in the form of statements and Visual Analog Scales (VAS).

The sample inclusion criteria were $7^{\text {th }}$ semester students of Faculty of Medicine and Health Sciences Universitas Muhammadiyah Yogyakarta possessing an android electronic communication device and consenting to install the application "Recognize and Control Allergic Nose" with symptoms of chronic rhinitis, productive age, and agreed to fill out the questionnaire. The sample exclusion criteria were those who had a history of chronic disease, such as hypertension and diabetes mellitus.

The dependent variable of this study was the QOL of people with chronic rhinitis, while the independent variable was chronic rhinitis which has been recorded as SFAR.

This research was conducted online via line application by sharing a link in the Google form containing informed consent and respondent identity data (initial name, age, and gender) and statements of respondents who agreed to participate in filling out the questionnaire honestly. The process was continued by filling out the allergic rhinitis diagnosis application with the contents of SFAR, and for the QOL in the form of statements and Visual Analog Scales (VAS).

The results were analysed using the Shapiro-Wilk normality test and the data were not normally distributed. Univariate analysis was performed for each variable to determine the distribution and percentage of each variable. The bivariate analysis was continued with the parametric contingency coefficient test because the two variables were nominal, to determine the correlation between the independent variable and the dependent variable.

\section{RESULT}

Table 1 showed that there were 20 male $(43.48 \%)$ and 26 female respondents $(56.52 \%)$. The sample used in this study had an age range from 20 to 24 years, with the highest number 21 years $(60.87 \%)$. Based on the SFAR it was found that the number was balanced, namely 23 respondents had a total score of $\geq 7(50 \%)$ and 23 respondents had a total score $<7(50 \%)$. From the SFAR results, the QOL of 25 respondents had a poor QOL $(54.35 \%)$ and 21 respondents had a good QOL (45.65\%).

Tabel 1. Sample Characteristic Data

\begin{tabular}{ccccc}
\hline & $\begin{array}{c}\text { Respondent's } \\
\text { characteristic }\end{array}$ & N (number) & \% & Total \\
\hline Gender & Male & 20 & 43.48 & 46 \\
& Female & 26 & 56.52 & 46 \\
Age & 20 & 5 & 10.87 & \\
& 21 & 28 & 60.87 & 46 \\
SFAR & 22 & 10 & 21.74 & \\
& 23 & 2 & 4.35 & 46 \\
Quality of Life & 24 & 23 & 50 & \\
& $<7$ & 23 & 50 & \\
\hline
\end{tabular}


The QOL consisted of 9 statements and VAS Parameters. Quality of life is good if the respondent obtained a VAS parameter score $<5$ and there was no statement that rhinitis complaints interfered with sleep/ daily activities. Whereas the respondent was considered to have poor QOL should the respondent obtained a VAS parameter score $\geq 5$ or at least one complaint statement that interfered with sleep/daily activities.
In Table 2, the statements in the questionnaire described the QOL of the respondent when the rhinitis complaint occurred. The results showed that the most statements among respondents were 24 students $(52.17 \%)$ who stated that rhinitis complaints would be reduced after using nasal drugs/sprays.

Tabel 2. Quality of Life statement

\begin{tabular}{lllll}
\hline Quality of life (Statements of complaint) & Yes & $\mathbf{\%}$ & No & $\mathbf{\%}$ \\
\hline Colds that interfered with daily activities & 16 & 34.78 & 30 & 65.22 \\
Bothering sneeze more than 5 times per episode & 11 & 23.91 & 35 & 76.09 \\
Nasal congestion that interfered daily activities & 15 & 32.61 & 31 & 67.39 \\
Did not have comfortable sleep & 14 & 30.43 & 32 & 69.57 \\
The QOL was disturbed due to nasal complaints & 14 & 30.43 & 32 & 69.57 \\
Required drugs to reduce nasal complaints & 10 & 21.74 & 36 & 78.26 \\
Nasal complaints disappeared without treatment & 15 & 32.61 & 31 & 67.39 \\
Itchy throat / itchy eyes that interfered with daily activities & 13 & 28.26 & 33 & 71.74 \\
Complaints lessened after the medicine I drank / nasal spray & 24 & 52.17 & 22 & 47.83 \\
\hline
\end{tabular}

VAS parameter was used to provide an assessment of pain when the complaint was felt as seen in Table 3. The results showed that the highest number given was 0 for 21 respondents, which meant that they did not feel any pain.

This study used the contingency coefficient test, the results showed that there was a positive correlation $(0.567)$ between the

Tabel 3. VAS Distribution Data for Quality of Life
SFAR and the QOL of patients with chronic rhinitis. These results indicated that the correlation categorized as moderate and the direction of the correlation is uni-directional, whereas the greater the score of one variable the greater the score of other variables. The significance score was also obtained, $\mathrm{p}=$ 0.000 which showed a significant correlation between the SFAR and the QOL of chronic rhinitis sufferers.

\begin{tabular}{ccccc}
\hline Quality of Life (VAS) & $\begin{array}{c}\text { Respondents' } \\
\text { characteristic }\end{array}$ & N (amount) & Total & \\
\hline VAS & 0 & 21 & 45.65 & 46 \\
1 & 6 & 13.04 & \\
2 & 2 & 4.35 \\
3 & 2 & 4.35 \\
4 & 2 & 4.35 \\
5 & 3 & 4.35 \\
6 & 2 & 6.52 \\
& 7 & 0 & 4.35 \\
& 8 & 0 & 0 \\
& & 2 & 0
\end{tabular}


Tabel 4. SFAR correlation test with QOL

\begin{tabular}{cccccc}
\hline Variable & Poor QOL & Good QOL & Total & $\begin{array}{c}\text { Correlation } \\
\text { Score }\end{array}$ & $\begin{array}{c}\text { Validity (p } \\
\text { value) }\end{array}$ \\
\hline SFAR $\geq 7$ & 19 & 4 & 23 & & \\
SFAR $<7$ & 6 & 17 & 23 & 0.567 & 0.000 \\
\cline { 1 - 2 } Total & 25 & 21 & 46 & & \\
\hline
\end{tabular}

\section{DISCUSSION}

The goal of management Allergic Rhinitis disease is not only symptoms improvement but also quality of life. Nonsedating antihistamine and intranasal corticosteroid with minimal adverse effects can improved the health-related quality of life measured by questionnaire HRQL. ${ }^{9}$ The Sinonasal Outcome Test (SNOT)-22 is a reliable validated questionnaire to assess the quality of life and symptom control of AR although it was developed for CRS disease. ${ }^{10}$

The benefits of using a mobile phonebased questionnaire for measuring patient self-reports have been recognized because it is efficient, convenient and easy in the distribution process. Several previous studies assessed therapy adherence and treatment outcomes on the quality of life of sufferers of asthma, allergic rhinitis and rhinosinusitis using a mobile phone application. ${ }^{11}$

The novelty of this study was the use of SFAR diagnostic tools and quality of life in one application which was connected with the results of the study which obtained a positive correlation value with moderate relationship strength $(\mathrm{r}=0.567)$. A positive correlation value indicated a uni-directional relationship, the greater the Score for Allergic Rhinitis, the greater the value of the poor quality of life.

The results was in line with the report of Bousquet et al. ${ }^{12}$ in 2017 which examined the management of AR control with a mobile phone application that contained daily reports of rhinitis symptoms with a score of 0 to
4 associated with EO-5D (EuroQuol) and WPAI-AS (Work Productivity and Activity Impairment in Allergy). The QOL data were similar in users without rhinitis and mild rhinitis (score $0-2$ ) and users with score 3 or 4 experienced a significant decrease in QOL.

In this study, a QOL questionnaire contained statements relating to the impact of disease and an assessment of the VAS score. To assess the degree of quality life complaint, the patient was asked to describe the value of VAS $\geq 5$ if it affected the sufferer's quality of life. In a study of patients with an SFAR score $\geq 7$, it was shown that $76 \%$ stated a VAS score $\geq 5$. The drawback of this study was that it did not assess the impact of AR disease specifically on sleep disorders, while Leger et al. ${ }^{13}$ in 2014 reported the incidence of sleep disturbances in subjects with severe rhinitis was significantly more often than subjects with mild rhinitis, although the duration of rhinitis did not affect sleep disturbances.

The first App to have tested for allergic rhinitis and conjunctivitis freely available in 20 countries contained of a simple questionnaire administered by cell phones enable identified the decreasing of quality of life such as work impairment and sleep disturbance caused of troublesome symptoms. ${ }^{14}$ Public awareness of RA is still low, sometimes even confused with influenza symptoms or viral infections, so that self-medication often occurs by buying over-the-counter medicines without an accurate diagnosis or consultation with a doctor. With a mobile phone application that contains a modified SFAR questionnaire, 
hopefully it will be able to help people to carry out screening easily, and in this application there are directions that could assist patients to overcome complaints with independent therapy, or advise patients to consult a doctor to control their allergic complaints.

Our study found that there was a significant correlation between the Score for Allergic Rhinitis and the quality of life in people with chronic rhinitis, and the correlation number obtained was 0.567 , indicating the strength of the correlation was moderate and uni-directional.

\section{REFERENCE}

1. Small P, Keith PK, Kim H. Allergic rhinitis. Allergy Asthma Clin Immunol. 2018; 14: 51.

2. Annesi-Maesano I, Didier A, Klossek M, Chanal I, Moreau D, Bousquet J. The score for allergic rhinitis (SFAR): A simple and valid assessment method in population studies. Allergy Eur J Allergy Clin Immunol. 2002; 57(2): 107-14.

3. Ologe FE, Adebola SO, Dunmade AD, Adeniji KA, Oyejola BA. Symptom score for allergic rhinitis. Otolaryngol - Head Neck Surg (United States). 2013; 148(4): 557-63.

4. Widuri A, Fahriani R. Validity and Reliability of the Indonesian Modification od Score for Allergic Rhinitis. Berkala kedokteran. 2021; 17(1): 1-6.

5. Dykewicz MS, Hamilos DL. Rhinitis and sinusitis. J Allergy Clin Immunol. 2010; 125: 103-15.

6. Keswani A, Peters AT. Complications of Rhinitis. Immunol Allergy Clin N Am. 2016; 36: 359-66.

7. Sybilski AJ. Visual analogue scale. A simple tool for daily treatment monitoring in allergic rhinitis. Pediatr Med Rodz. 2018; 14: 277-81.

8. Matricardi PM et al. The role of mobile health technologies in allergy care: An EAACI position paper. Allergy. 2019: 1-14.

9. Meltzer EO. Quality of life in adults and children with allergic rhinitis. J Allergy Clin Immunol. 2001; 108: 45-53.

10. Husain Q, Hoehle L, Phillips K, Caradonna DS, Gray ST, Sedaghat AR. The 22-Item Sinonasal Outcome Test as a Tool for the
Assessment of Quality of Life and Symptom Control in Allergic Rhinitis. Am J Rhinol Allergy. 2020 ; 34(2): 209-16.

11. Tripodi S, Giannone A, Sfika I, Pelosi S, Dramburg S, Bianchi A, et al. Digital technologies for an improved management of respiratory allergic diseases: 10 years of clinical studies using an online platform for patients and physicians. Ital J Pediatr. 2020; 46(1): $1-11$

12. Bousquet J, Arnavielhe S, Bedbrook A, Fonseca J, Morais Almeida M, Todo Bom A, et al. The Allergic Rhinitis and its Impact on Asthma (ARIA) score of allergic rhinitis using mobile technology correlates with quality of life: The MASK study. Allergy Eur J Allergy Clin Immunol. 2018; 73(2): 505-10.

13. Léger D, Annesi-Maesano I, Carat F, Rugina M, Chanal I, Pribil C, et al. Allergic rhinitis and its consequences on quality of sleep: An unexplored area. Arch Intern Med. 2006; 166(16): 1744-48.

14. Bousquet J, Caimmi DP, Bedbrook A, Bewick M, Hellings PW, Devillier P, et al. Pilot study of mobile phone technology in allergic rhinitis in European countries: the MASK-rhinitis study. Allergy 2017; 72: 857-65. 